\title{
A COMPARATIVE STUDY OF CLINICO-IMMUNOLOGICAL RESPONSE TO HIGHLY ACTIVE ANTIRETROVIRAL THERAPY IN HIV AND HIV-HCV CO-INFECTION IN MANIPUR
}

\author{
Amrita Mangar 1 , Narmada Thongam², Thongam Bhimo Singh ${ }^{3}$, Karam Romeo Singh ${ }^{4}$, R.K. Narendra Singh 5 \\ 1 Postgraduate Student, Department of Medicine, RIMS, Imphal. \\ ${ }^{2}$ Assistant Professor, Department of Biochemistry, JNIMS, Imphal. \\ ${ }^{3}$ Professor, Department of Medicine, JNIMS, Imphal. \\ ${ }_{4}^{4}$ Associate Professor, Department of Medicine, RIMS, Imphal. \\ 5 Professor \& Head, Department of Biostatistics, RIMS, Imphal.
}

\section{ABSTRACT}

\section{BACKGROUND}

HIV-HCV co-infection is common in Manipur because of the increase in number of intravenous drug users (IDUs) and being eastern border state of India. HIV-HCV patients die of liver complications in spite of highly active antiretroviral therapy (HAART). The aim of the present study is to compare the clinico-immunological response to highly active antiretroviral therapy in HIV and HIV-HCV co-infection in Manipur.

\section{MATERIALS AND METHODS}

The present study was conducted in 45 HIV mono-infected (Group-I) and 45 HIV-HCV co-infected (Group-II) patients who were on first line antiretroviral treatment (ART).

\section{RESULTS}

In the present study, the clinico-immunological (CD4) response to ART in both the groups was recorded. The commonest route of transmission is heterosexual (62.2\% and 53.3\%) activity followed by IDUs (31\% and 37\%). The trend of CD4 is almost coinciding at initial $188.86 \pm 104.27$ Vs. $179.00 \pm 98.19$ cells $/ \mathrm{mm}^{3}$ but mean CD 4 for HIV group is higher at $6^{\text {th }}$ month, at $12^{\text {th }}$ month and at $18^{\text {th }}$ month with $502.82 \pm 272.22$ Vs. $412.47 \pm 229.48$ cells $/ \mathrm{mm}^{3}$ after ART as compared to HIV-HCV group significantly P $<0.05$ $(\mathrm{P}=0.032)$. Further, the CD4 response was better in HIV-HCV with treatment of both HIV and HCV than without HCV treatment.

\section{CONCLUSION}

The present study showed that the immunological response to ART to both HIV and HIV-HCV co-infection groups is good, but better in HIV group. Further, amongst the HIV-HCV co-infection the immunological response was better to those who had undergone HCV treatment. So routine screening for HCV in HIV infected patients and starting HCV treatment early will result in better quality of life.

\section{KEYWORDS}

Highly Active Antiretroviral Therapy, Antiretroviral Treatment, Intravenous Drug Users.

HOW TO CITE THIS ARTICLE: Mangar A, Thongam N, Singh TB, et al. A comparative study of clinico-immunological response to highly active antiretroviral therapy in HIV and HIV-HCV co-infection in Manipur. J. Evolution Med. Dent. Sci. 2017;6(24):19681971, DOI: $10.14260 / \mathrm{Jemds} / 2017 / 431$

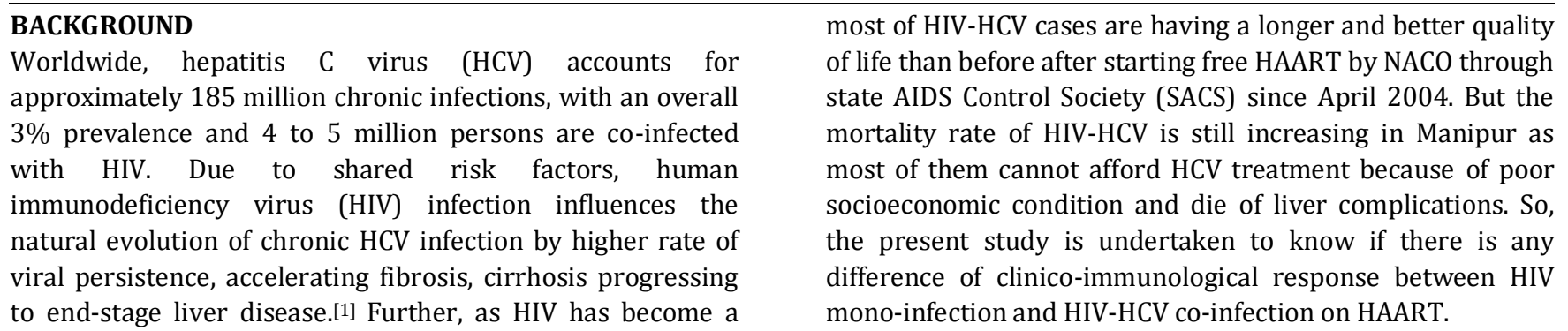
chronic illness due to the effectiveness of highly active antiretroviral therapy (HAART), HCV related liver disease has emerged as a major cause of morbidity and mortality among HIV infected patients in the developed world. [2] In Manipur

Financial or Other, Competing Interest: None.

Submission 13-02-2017, Peer Review 09-03-2017,

Acceptance 15-03-2017, Published 22-03-2017.

Corresponding Author:

Dr. Thongam Bhimo Singh,

Uripok Ningthoukhongjam Leikai,

Imphal, Manipur-795001.

E-mail: bhimoth@yahoo.co.in

DOI: $10.14260 /$ jemds $/ 2017 / 431$

\section{Aims and Objectives}

To assess and compare clinico-immunological response (CD4 count) to Highly Active Antiretroviral Therapy in HIV and HIV-HCV co-infection patients.

\section{MATERIALS AND METHODS}

The study was carried out in the Department of Medicine, Regional Institute of Medical Sciences, Imphal from October 2014 to March 2016. The study was a single centre prospective cohort study. Out of total 1420 registered patients, 1360 were HIV mono-infected and 60 were HIV-HCV co-infected patients. Of these 90 patients who fulfilled 
inclusion and external criteria, 45 HIV mono-infected (GroupI) and 45 HIV-HCV co-infected (Group-II) who were on first line treatment were included in the study. The sample size was calculated based on the mean CD4 count and standard deviation of HIV mono-infected and HIV-HCV co-infected patients from the previous study.[Ref: Taye $S$ et al3].

Thorough clinical examination, laboratory investigations such as complete blood count, liver function test, kidney function test, random blood sugar, chest x-ray and CD4 count were done. The presence of HIV infection was confirmed as per the National AIDS Control Organization (NACO) guidelines using 3 (three) ER (ELISA Rapid) HIV test kit. CD4 cell count was calculated by Fluorescence Activated Cell sorter (Manufacturer: BD Biosciences 2350 Qume Drive, San Jose, CA 95131-1807, USA) and HCV viral load was measured by Real Time PCR (Manufacturer: ROCHE and Thermo Scientific). All the patients gave written informed consent and approval was taken from institutional ethical committee before the study.

\section{Statistical Analysis}

Statistical analysis was done by using the Statistical Package for Social Sciences (SPSS) 20 version. Numerical continuous variables are presented as Mean \pm SD (Standard deviation) and qualitative/categorical variables are again described as number of cases and percentages. The two means for each parameter between HIV and HIV+HCV groups are compared by Independent Sample Test ( $\mathrm{t}$-test); the variation of two means at two different stages for each parameter within group are tested by Paired t-test; the variation of more than two means at different stages for each parameter within group is tested by Friedman's Two-Way ANOVA; and $\chi^{2}$-test is applied for categorical variables. All comparisons are twosided and the $\mathrm{P}$ - values of $<0.05$ and $<0.01$ are treated as the cut-off values for significance and highly significance respectively.

\section{RESULTS}

The clinico-immunological (CD4) response to highly active antiretroviral therapy on both the groups were recorded. In group I and group II, the ratio of male: female was 60:40 and 84.4: 15.6 respectively thereby showing the higher prevalence of males in both the groups $(P=0.010)$. The number of married persons in both group I and group II were $69 \%$ and $86 \%$ showing the importance of sexual route of transmission. The average age of patients in HIV group was around 40 years and 43 years in HIV-HCV group which shows that both HIV and HIV-HCV are common in the fertile period. In both the groups, highest mode of transmission was found to be heterosexual (62.2\% and 53.3\%) activity followed by intravenous drug usage (31\% and $37 \%$ ). However, in the HIV group, infections due to blood transfusion, mother to child, and unsafe injections were very less with same percentage i.e., $2.2 \%$ each. In HIV-HCV group, unsafe injection (6.7\%), blood transfusion $(2.2 \%)$ and no case of mother to child transmission was found.

Mean \pm SD: mean and standard deviation; t: independent sample test; d.f.: degree of freedom; P: Probability of difference due to chance factors; n: number of cases.

\begin{tabular}{|c|c|c|c|c|c|c|c|}
\hline \multirow{2}{*}{$\begin{array}{l}\text { Parameters } \\
\text { cells } / \mathbf{m m}^{3}\end{array}$} & \multicolumn{4}{|c|}{ Groups } & \multirow[b]{2}{*}{$\begin{array}{c}\mathrm{t} \\
\text { value }\end{array}$} & \multirow[b]{2}{*}{ d. f. } & \multirow{2}{*}{$\begin{array}{c}P \text { - } \\
\text { value }\end{array}$} \\
\hline & $\mathbf{N}$ & $\begin{array}{c}\text { HIV } \\
\text { (Group I) }\end{array}$ & $\mathbf{N}$ & $\begin{array}{l}\text { HIV-HCV } \\
\text { (Group II) }\end{array}$ & & & \\
\hline $\begin{array}{c}\text { CD4 } \\
\text { (baseline) }\end{array}$ & 45 & $\begin{array}{c}188.86 \pm \\
104.27\end{array}$ & 45 & $\begin{array}{c}179.00 \pm \\
98.19\end{array}$ & 0.462 & 88 & 0.645 \\
\hline $\begin{array}{l}\text { CD4 after } \\
6 \text { months }\end{array}$ & 45 & $\begin{array}{c}393.82 \pm \\
195.54\end{array}$ & 45 & $\begin{array}{c}310.64 \pm \\
173.09 \\
\end{array}$ & 2.137 & 88 & 0.035 \\
\hline $\begin{array}{l}\text { CD4 after } \\
12 \text { months }\end{array}$ & 45 & $\begin{array}{c}49.78 \pm \\
249.48 \\
\end{array}$ & 45 & $\begin{array}{c}368.71 \pm \\
230.59 \\
\end{array}$ & 2.601 & 88 & 0.013 \\
\hline $\begin{array}{l}\text { CD4 after } \\
18 \text { months }\end{array}$ & 45 & $\begin{array}{c}502.82 \pm \\
272.22\end{array}$ & 45 & $\begin{array}{c}412.47 \pm \\
229.48\end{array}$ & 2.702 & 88 & 0.032 \\
\hline & & 1. Group & & Distribu & - & & \\
\hline
\end{tabular}

Table 1. Shows that there is no variation of mean $\mathrm{CD}_{4}$ between the groups in initial but after $6^{\text {th }}, 12^{\text {th }}$ and 18 th month of ART, mean CD4 between the groups are found to be significant at $5 \%$ probability level as corresponding $\mathrm{P}<0.05$ $(P=0.032)$.

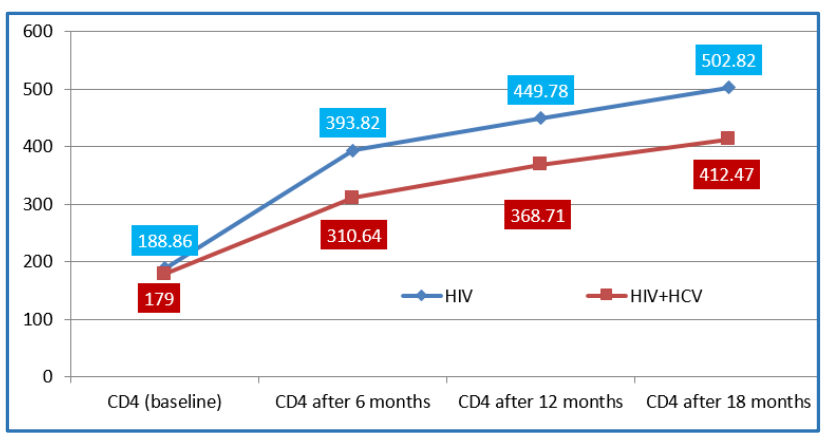

Figure 1. Shows the Trend of CD4 is almost Coinciding at Initial but Mean CD4 for HIV Group is higher at $6^{\text {th }}$ month, at $12^{\text {th }}$ month and at $18^{\text {th }}$ month after ART as Compared to HIV-HCV Group Significantly.

\begin{tabular}{|c|c|c|c|c|c|c|c|}
\hline \multirow{2}{*}{$\begin{array}{c}\text { Para- } \\
\text { meters } \\
\text { cells } / \mathbf{m m}^{3}\end{array}$} & \multicolumn{4}{|c|}{ Group II } & \multirow[b]{2}{*}{$\begin{array}{c}\mathrm{t} \text { - } \\
\text { value }\end{array}$} & \multirow[b]{2}{*}{ d.f. } & \multirow{2}{*}{$\begin{array}{c}P \text { - } \\
\text { value }\end{array}$} \\
\hline & $\mathbf{N}$ & $\begin{array}{c}\text { HCV, No } \\
\text { Treatment }\end{array}$ & $\mathbf{N}$ & $\begin{array}{c}\text { HCV } \\
\text { Treatment }\end{array}$ & & & \\
\hline $\begin{array}{c}\text { CD4 } \\
\text { (Baseline) }\end{array}$ & & $\begin{array}{c}198.84 \pm \\
98.09\end{array}$ & & $\begin{array}{r}104 \\
\pm 94 .\end{array}$ & 1.539 & 43 & 0.131 \\
\hline $\begin{array}{l}\text { CD4 after } \\
6 \text { months }\end{array}$ & 25 & $\begin{array}{c}338.28 \pm \\
182.15\end{array}$ & 20 & $\begin{array}{c}276.10 \pm \\
158.79\end{array}$ & 1.203 & 43 & 0.235 \\
\hline $\begin{array}{l}\text { CD4 after } \\
12 \text { months }\end{array}$ & 19 & $\begin{array}{c}499.10 \pm \\
318.86\end{array}$ & 16 & $\begin{array}{c}476.81 \pm \\
293.17\end{array}$ & .214 & 33 & 0.832 \\
\hline $\begin{array}{c}\text { CD4 after } \\
18 \text { months }\end{array}$ & 6 & $\begin{array}{c}389.25 \pm \\
77.13\end{array}$ & 4 & $\begin{array}{c}556.33 \pm \\
271.35\end{array}$ & 1.589 & 8 & 0.632 \\
\hline
\end{tabular}

Table 2. Treatment-wise Comparison of Mean \pm SD of $\mathrm{CD}_{4}$ for HIV-HCV at Various Stages (with and without HCV treatment)

Table 2. Shows that the CD4 increased variations are not significant even at $5 \%$ probability level $(\mathrm{P}=0.632)$.

\section{DISCUSSION}

HCV-HIV co-infection is common among the IDUs in Manipur, but longer life span seen after free ART was started by NACO through SACS since April 2004. However, these HIV-HCV coinfection patients die prematurely because of liver complications including HCC of HCV in spite of ART. The lesser number of patients on HCV treatment is because HCV treatment is costly and unaffordable. In the present study, males are affected than females (60\% Vs. 40\%) in Group I and (84.4\% Vs. $15.6 \%)$ in Group II. The highest prevalence is 
found in the age group 40-45 years in both the groups which is in agreement with the work of Taye $S$ et al.[3] The mode of transmission in the present study is highest in both the groups with heterosexual (62\% Vs. 53\%) activity followed by intravenous drug users (37\% Vs. 31\%) respectively in contrast to other previous studies where HIV-HCV coinfection was found more among IDUs.[4,5,6]

The reason being HCV screening test was done routinely in all HIV patients in the present study before ART in contrast to other study by Rockstroh J et al[7] where HCV screening test was done only in the high risk group i.e. IDUs.

In the present study, there is no significant variation of mean $\mathrm{CD}_{4}$ count between the two groups I and II before starting HAART $(188.86 \pm 104.27$ Vs. $179.00 \pm 98.19$ $\mathrm{P}=0.645)$. But after $6^{\text {th }}(393.82 \pm 195.54$ Vs. $310.64 \pm 173.09$ $\mathrm{P}=0.035), 12^{\text {th }}(449.78 \pm 249.48$ Vs. $368.71 \pm 230.59$ $\mathrm{P}=0.013), 18^{\text {th }}(502.82 \pm 272.22$ Vs. $412.47 \pm 229.48$, $\mathrm{P}=0.032$ ) months of HAART, the range of revised CD4 count was higher in Group-I than in Group-II which is statistically significant. Taye $\mathrm{S}$ et al[3] found that the increased CD4 was higher in HIV than HCV co-infected group on HAART (426 Vs. 343; $\mathrm{P}<0.004)$. Braintstein $\mathrm{P}$ et al[8] also found that HCV negative patients had CD4 increase of an average of 75 cells in the absolute CD4 cell count and $4.4 \%$ in the CD4 cell fraction, compared with 20 cells and $1.1 \%$ in HCV positive patients, after 48 weeks of ART. Miller M et al[9] also found that the HIV-HCV co-infected patients had a mean increase in the CD4 cell count with 33.4 cells $/ \mathrm{mm}^{3}$ (95\% CI, 23.5-43.3 cells $/ \mathrm{mm}^{3}$ ) less than that for HIV mono-infected patients. These findings are similar to previous studies where there was negative impact on immune recovery by HCV coinfection in HIV patients. $[3,4,8,9,10,11,12,13,14]$ In our study, the adherence rate was high in both the groups (97\%), so this could be one of the reason for good immune response. This is similar to the study conducted by Abrogoua $\mathrm{D}$ et al[15] as the baseline CD4 cell count was $<200 / \mathrm{mm}^{3}$ in both the groups and the increased CD4 response after 6 months of HAART was $>100 / \mathrm{mm}^{3}$ in both the groups during the 18 months period. In Group II only 20 patients could afford treatment of HCV. The increase of CD4 count was $198.84 \pm 98.09$ at baseline and at $389.25 \pm 77.13$ after the $18^{\text {th }}$ month without HCV treatment.

But in HCV treated HIV patients (Injection Peginterferon and Tab. Ribavirin), the increase of CD4 count was $154.20 \pm 94.90$ at baseline and $556.33 \pm 271.35$ after the $18^{\text {th }}$ month of HCV treatment. This shows that treatment of HCV in HIV-HCV had better immunological response than those with no HCV treatment. The genotypes were 2, 3, 1 and 6 . There is a variation of liver enzyme SGPT and SGOT level between the two groups. The liver enzyme level was higher in HIV + HCV group as compared to mono-infected group (85.53 \pm 12.55 Vs. $35.48 \pm 13.59$ and $72.08 \pm 11.59$ Vs. $31.57 \pm 11.75$; $\mathrm{P}=$ .043) which suggests that HCV causes the chronic liver infection. There was no significant disparity of mean RBS level between two groups $(101.71 \pm 18.49$ Vs. $111.96 \pm 20.21$; $p=0.952$ ). None of the patients were diabetic though 03 cases in HIV group and 04 cases in HIV+HCV group were in the impaired glucose tolerance range. There was increase in weight in both HIV and HIV-HCV co-infected after 6 months of HAART $(3.5 \pm 1.6 \mathrm{~kg}$ and $3 \pm 1.2 \mathrm{~kg}$ respectively). In the present study, there was no death due to liver disease among the study population during the period of study as the other causes like alcohol, HBV infection were excluded. This study is in agreement with Carmo $\mathrm{R}$ et al[14] where there was no increased risk of progression to new AIDS-defining clinical events or death caused by AIDS after the initiation of HAART. In our study, maximum (95.6\%) patients were on TLE regimen which was recently changed according to NACO guidelines 2013. There was no major serious adverse effect of the regimen though the renal toxicity is a common side effect of tenofovir but it will depend on the dose and duration of the treatment.

\section{CONCLUSION}

The present study showed that the immunological response to ART to both HIV mono-infection and HIV-HCV co-infection groups was good, though the response was better in HIV mono-infection group. Further, amongst the HIV-HCV coinfection, the immunological response was better to those who had undergone HCV treatment. The HCV seropositivity was not associated with an increased risk of progression to a new AIDS-defining opportunistic illness or death after the initiation of ART. So, routine screening for HCV in HIV infected patients and starting HCV treatment early will result in better quality of life.

\section{REFERENCES}

[1] Resino S, Bellón J, Asensio C, et al. Can serum hyaluronic acid replace simple non-invasive indexes to predict liver fibrosis in HIV/Hepatitis C co-infected patients. Clin Liver Dis 2010;10:244.

[2] Garcia-Samaniego J, Rodriguez M, Berenguer J, et al. Hepatocellular carcinoma in HIV-infected patients with chronic hepatitis C. The American Journal of Gastroenterology 2001;96(1):179-83.

[3] Taye S, Lakew M. Impact of hepatitis C virus coinfection on HIV patients before and after highly active antiretroviral therapy: an immunological and clinical chemistry observation, Addis Ababa, Ethiopia. BMC Immunol 2013;14(1):23.

[4] Weis N, Lindhardt B, Kronborg G, et al. Impact of hepatitis $\mathrm{B}$ virus co-infection on response to highly active antiretroviral treatment and outcome in HIVinfected individuals: a nationwide cohort study. Clinical Infectious Diseases 2006;42(10):1481-7.

[5] Anderson KB, Guest JL, Rimland D, et al. Hepatitis C virus co-infection increases mortality in HIV-infected patients in the highly active antiretroviral therapy era: data from the HIV Atlanta VA cohort study. Clinical Infectious Diseases 2004;39(10):1507-13.

[6] Babik JM, Holodniy M. Impact of highly active antiretroviral therapy and immunologic status on hepatitis $\mathrm{C}$ virus quasispecies diversity in human immunodeficiency virus/hepatitis C virus-co-infected patients. Journal of Virology 2003;77(3):1940-50.

[7] Rokstroh JK, Mocroft A, Soriano V, et al. Influence of hepatitis C virus infection on HIV-1 disease progression and response to highly active antiretroviral therapy. The Journal of Infectious Diseases 2005;192(6):992-1002. 
[8] Braitstein P, Zala C, Yip B, et al. Immunologic response to antiretroviral therapy in hepatitis C virus-coinfected adults in a population-based HIV/AIDS treatment program. The Journal of Infectious Diseases 2006;193(2):259-68.

[9] Miller MF, Haley C, Koziel MJ, et al. Impact of hepatitis $\mathrm{C}$ virus on immune restoration in HIV-infected patients who start highly active antiretroviral therapy: a meta-analysis. Clinical Infectious Diseases 2005;41(5):713-20.

[10] Motta D, Brianese N, Focà E, et al. Virological effectiveness and CD4+ T-cell increase over early and late courses in HIV infected patients on antiretroviral therapy: focus on HCV and anchor class received. AIDS Res Ther 2012;9:18.

[11] Greub G, Ledergerber B, Battegay M, et al. Clinical progression, survival, and immune recovery during antiretroviral therapy in patients with HIV-1 and hepatitis C virus co-infection: the Swiss HIV cohort study. Lancet 2000;356(9244):1800-5.
[12] Anderson JP, Horsburgh CR, Williams PL, et al. CD4 recovery on antiretroviral therapy is associated with decreased progression to liver disease among hepatitis $C$ virus-infected injecting drug users. Open Forum Infectious Diseases 2015;2(1):ofv019.

[13] Sajadi MM, Pulijala R, Redfield RR, et al. Chronic immune activation and decreased CD4 counts associated with hepatitis C infection in HIV-1 natural viral suppressors. AIDS 2012;26(15):1879-84.

[14] Carmo RA, Guimarães M, Moura A, et al. The influence of HCV co-infection on clinical, immunological and virological responses to HAART in HIV-patients. Brazilian Journal of Infectious Diseases 2008;12(3):173-9.

[15] Abrogoua DP, Kablan BJ, Aulagner G, et al. Assessment of the impact of adherence and other predictors during HAART on various CD4 cell responses in resource-limited settings. Patient Preference and Adherence 2012;6:227-37. 